Received: $10-\mathrm{VI}-2020$

Accepted: 13-VII-2020

Published Online: $17-\mathrm{VII}-2020$

\section{The Effects of Mouthwashes on the Color Stability of Resin-Based} Restorative Materials

\section{Efecto de los enjuagues orales en la estabilidad del color de} materiales restauradores a base de resina

Ayşe Tuğba Ertürk-Avunduk DDS, MDs; Seçkin Aksu DDS, MDs²; Ebru Delikan DDS, MDs³

1. Mersin University, Faculty of Dentistry, Department of Restorative Dentistry, Mersin, Turkey.

2. Mersin University, Faculty of Dentistry, Department of Pediatric Dentistry, Mersin, Turkey.

3. Nuh Naci Yazgan University, Faculty of Dentistry, Department of Pediatric Dentistry, Kayseri, Turkey.

Correspondence to: Dr. Ayşe Tuğba Ertürk-Avunduk - aysetugba11@gmail.com

ABSTRACT: Objective: This study investigated the effects of three types of mouthwash on the color stability of three resin-based restorative materials (nanohybrid resin composite, sonic-activated bulk-fill material, and compomer). Materials and Methods: To this end, 120 cylindrical disc specimens were prepared and polished, after which they were incubated in distilled water for 24 hours for post-polymerization. The baseline color values of each specimen were measured with a spectrophotometer, then the specimens were randomly divided into four groups. Following immersion in the mouthwashes for 24 hours, the specimens were rinsed with distilled water and dried before the color measurement was repeated. The values of color change $\left(\Delta \mathrm{E}_{00}\right)$ were subsequently calculated. A two-way analysis of variance and Duncan's post hoc multiple comparison tests were conducted to determine statistically significant differences among the restorative materials. Results: All samples showed discoloration after immersion, albeit some instances of discoloration were imperceptible. In this respect, a statistically significant difference was found among the restorative materials and mouthwashes $(p<0.05)$. Imperceptible $\Delta$ Eoo values were derived on the nanohybrid resin composite and compomer, but perceptible and acceptable $\Delta$ Eoo values were detected on the sonic-activated bulk-fill materials $(p<0.05)$. The clinically unacceptable discoloration was observed on the sonic-activated bulk-fill composite immersed in Listerine $®$. Conclusions: Clinicians should make recommendations based on the potential staining capacity of mouthwashes prescribed for daily use in restorative materials. In this way, the need for renewal of restorations due to discoloration could be avoided. 
KEYWORDS: CIEDE2000; Color stability; Compomer; Dental Materials; Mouthwash; Resin Composite.

RESUMEN: Objetivo: Este estudio investigó los efectos de tres tipos de enjuague bucal en la estabilidad del color de tres materiales de restauración a base de resina (resina nanohíbrida, resina bulk-fill de activación sónica y compómero). Materiales y Métodos: Para ello se prepararon y pulieron 120 muestras de discos cilíndricos, después de lo cual se incubaron en agua destilada durante 24 horas pospolimerización. Los valores de color de base de cada muestra se midieron con un espectrofotómetro, después las muestras se dividieron aleatoriamente en cuatro grupos. Tras la inmersión en los enjuagues bucales durante 24 horas, los especímenes se enjuagaron con agua destilada y se secaron antes de repetir la medición del color. Posteriormente se calcularon los valores de cambio de color $\left(\Delta E_{00}\right)$. Se llevó a cabo un análisis bidireccional de la varianza y las pruebas de comparación múltiple post hoc de Duncan para determinar las diferencias estadísticamente significativas entre los materiales de restauración. Resultados: Todas las muestras mostraron decoloración después de la inmersión, aunque algunos casos esta fue imperceptible. Se encontró una diferencia estadísticamente significativa entre los materiales de restauración y los enjuagues bucales $(p<0,05)$. Se obtuvieron valores imperceptibles de $\Delta$ Eoo en el compuesto de resina nanohíbrida y el compómero, pero se detectaron valores perceptibles y aceptables de $\Delta E_{0 o}$ en la resina bulk-fill activada sónicamente $(p<0,05)$. Se observó una decoloración clínicamente inaceptable en la resina bulk-fill activada sónicamente inmersa en Listerine ${ }^{\circledR}$. Conclusiones: Los clínicos deben hacer recomendaciones basadas en la capacidad potencial de coloración de los enjuagues bucales prescritos para uso diario en los materiales de restauración. De esta manera, se podría evitar la necesidad de renovar las restauraciones debido a la decoloración.

PALABRAS CLAVE: CIEDE2000; Estabilidad de color; Compómero; Materiales dentales; Enjuague oral; Resina.

\section{INTRODUCTION}

Dental materials should have good esthetic properties, biocompatibility, and functionality. Esthetic expectations and advances in dental technology have made it necessary to ensure a desirable appearance and durability also in posterior teeth (1). The challenge is that further improvement is still needed as regards the esthetic features of glass ionomers, composite resins, and modified resin-based systems, which are frequently used in restorative and pediatric dentistry (2). This issue finds resolution in the development of bulk-fill composite resins, which can be applied up to an average thickness of $5 \mathrm{~mm}$. These materials minimize polymerization shrinkage and improve marginal adaptation because of their high fluidity and sonic activation properties (3).

Given today's increasing esthetic expectations, the most crucial success criteria for restorative dentistry are ensuring color harmony and stability between teeth and restorations in the long term. Discoloration due to external sources or internal factors can even be detected in materials that exhibit color harmony with tooth tissue (4). Internal factors that affect color stability originate from a 
material's structure and include effects such as the oxidation of amine accelerators; this oxidation is required for polymerization but increases liquid absorption. External factors are related to the liquid and solid foodstuffs consumed daily and influenced by systemic conditions, nutritional and oral hygiene habits, and the surface roughness of restorations $(4,5)$. Frequently consumed beverages, such as juice, tea, coffee, and cola, likewise increase discoloration in dental materials $(6,7)$.

Mouthwashes and medicines may also cause discoloration on teeth and restorations. The latter, which should be recommended only in specific situations, is used in the supportive treatment of periodontal diseases and halitosis, the prevention of dental plaque formation during orthodontic treatments and surgical operations, and the healing of mucositis after chemotherapy and radiotherapy $(8,9)$. Oral mouthwashes generally contain chlorhexidine gluconate, ethanol, essential oils, and detergents. They can also be incorporated with anti-inflammatories, anesthetics, antibacterial, antifungals, antihistamines, and remineralizing agents. Finally, these products can contain moisturizers, flavorings, colorings, and stabilizers (10). The frequent use of mouthwash can damage soft tissues and oral flora, create a temporary loss of taste sensation, and adversely affect the surface properties of restorations $(9,10)$.

Chlorhexidine gluconate, a cationic antiseptic agent and mouthwash, is prescribed by dentists for its bactericidal properties, yet it is also the greatest cause for concern in terms of color stability. It is therefore one of the substances frequently used in color stability studies involving mouthwashes (11-13). Due to the staining effect of chlorhexidine gluconate, mouthwashes with different contents that minimize this effect are introduced to the market. Although there are studies on this subject, the literature review revealed limited data regarding the staining effect

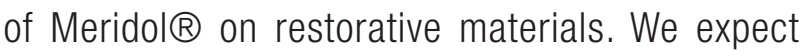

the evaluation of various types of mouthwashes with modern and improved ingredients to provide a positive contribution to the literature. Accordingly, the current study inquired into the effects of three types of mouthwash on the color stability of nanohybrid, bulk-fill, and polyacid-modified composite resin-based restorative materials. The null hypotheses tested were as follows: (a) No significant difference exists between mouthwashes in terms of staining restorative materials, and (b) no significant difference is found between restorative materials with respect to ensuring color stability.

\section{MATERIALS AND METHODS}

Nanohybrid resin composite [Nova-Compo-N (NC)], sonic-activated bulk-fill material [SonicFill (SF)], and compomer [Dyract-XP (DXP)] were treated with three types of mouthwashes [Andorex

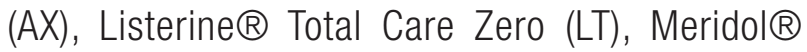
$(\mathrm{ML})$ ] and distilled water. Details regarding these materials are presented in Table 1 and Table 2 . B2 shade was used as the standard for all the composite resin brands, and 120 cylindrical disc specimens (40 specimens for each material) were prepared using Teflon molds (diameter $10 \mathrm{~mm}$ and thickness $2 \mathrm{~mm}$ ). A transparent polyester strip band (Mylar strip; SS White Co. Philadelphia, PA, USA) and glass plate were used in the application of light pressure to remove excess material and obtain a smooth surface. The specimens were polymerized using an LED device (Planmeca Lumion, Planmeca Oy, Helsinki, Finland) with a light intensity of 600 $\mathrm{mW} / \mathrm{cm}^{2}$. The distance between the light source and the sample was standardized using a $1 \mathrm{~mm}$ transparent polyester strip band. After polishing with a Super-Snap Rainbow Technique Kit (Shofu, Inc., Kyoto, Japan) and One Gloss Polishing Kit (Shofu, Inc., Kyoto, Japan), the specimens were immersed in distilled water with a temperature of $37^{\circ} \mathrm{C}$ for $24 \mathrm{~h}$ for post-polymerization.

The initial color values (To) of the samples were measured using an Easy shade V (Vita Zahnfabrik, 
Germany) digital spectrophotometer operated in "shade of restoration" mode. The device was first calibrated using a white calibration plate in accordance with the manufacturer's recommendations, and then measurements were performed by placing the measurement tip perpendicular to the sample surface to be measured, with no gap between the tip and the surface. The device was recalibrated after every 10 samples measured. The measurements were repeated three times for each sample, and mean values were subjected to analysis.

The samples were randomly divided into four groups before immersion in mouthwash solutions (AX, LT, and ML) and distilled water. The number of samples to be studied was estimated via a power analysis using $\mathrm{G}^{*}$ Power, with a power of $90 \%$ and an assumed significance level of .05 implemented in the estimation. A sample size of $n=10$ was determined. The 12-hour immersion period in solutions corresponds to 1 minute of mouthwash use twice a day for 1 year (26). For this reason, in our study, samples were kept in solutions for 24 hours (13), which was determined to be equivalent to one minute twice a day for 2 years.

Following, the samples washed with distilled water, and dried with a sponge, after which the color measurement procedures were repeated $\left(T_{1}\right)$. These procedures are summarized in Figure 1. The changes in color values $\left(\Delta E_{00}\right)$ between To and $T_{1}$ were calculated using the CIEDE2000 color system and the following formula (14):

$$
\Delta \mathrm{E}_{00}=\left[\left(\frac{\Delta L}{k_{L} S_{L}}\right)^{2}+\left(\frac{\Delta C}{k_{C} S_{C}}\right)^{2}+\left(\frac{\Delta H}{k_{H} S_{H}}\right)^{2}+R_{T}\left(\frac{\Delta C}{k_{C} S_{C}}\right)\left(\frac{\Delta H}{k_{H} S_{H}}\right)\right]^{1 / 2}
$$

Where $\Delta \mathrm{L}, \Delta \mathrm{C}$, and $\Delta \mathrm{H}$ represent the differences in lightness, chroma, and hue between the initial and subsequent color measurements, respectively. SL, SC, and SH are the functions of weight, incorporated into the formula to eliminate the irregularities observed in the CIE L*a*b system; they refer to brightness, color density, and hue, respectively (weighting functions) (14). These values reflect the total color difference among $L^{*}, a^{*}$, and $b^{*}$ values in two different coordinates. RT represents the rotation function/rotation term that shows the extent of interaction between color intensity and color tone differences in the blue area in the CIE $L^{*} a^{*} b$ color system (15). For RT, a value of $0(\triangle C=0)$ is assumed for colors falling within the same color density radius. $\mathrm{KL}, \mathrm{KC}$, and $\mathrm{KH}$ are parametric factors calculated for lightness, color chroma and hue, respectively. These were included in the formula to correct errors arising from experimental conditions, such as the surface of a material and the background against which a measurement was performed. The CIEDE (1:1:1) system was used, in which the parametric values were taken as '1' (16). Additionally, 2.25 units reported as indicative of a 50:50\% acceptability threshold were used in the clinical interpretation of color changes $(5,17)$.

All statistical analyses were performed using the Statistical Package for the Social Sciences (SPSS Inc., Chicago, IL, USA). Data distribution was checked for normalcy using the KolmogorovSmirnov test, and a two-way analysis of variance was conducted to determine statistically significant differences among the restorative materials immersed in each mouthwash. In the event of a significant difference between the materials, Duncan's post hoc multiple comparison test was performed. The level of statistical significance was set at $p=0.05$. 
Table 1. Compositions of the composite resin materials.

\begin{tabular}{|c|c|c|c|c|c|c|c|}
\hline $\begin{array}{l}\text { Restorative } \\
\text { materials }\end{array}$ & Type & Filler Composition & $\begin{array}{l}(\%) \\
\text { Weight, } \\
\text { Volume }\end{array}$ & $\begin{array}{c}\text { Particle } \\
\text { size }\end{array}$ & $\begin{array}{l}\text { Manu- } \\
\text { facturer }\end{array}$ & $\begin{array}{c}\text { Lot } \\
\text { (batch) no }\end{array}$ & Code \\
\hline $\begin{array}{c}\text { Nova } \\
\text { Compo N }\end{array}$ & $\begin{array}{l}\text { Nano-hybrid } \\
\text { universal resin } \\
\text { composite }\end{array}$ & $\begin{array}{c}\text { St glass, nano ytterbium trifluoride, } \\
\text { silica, BIS-GMA, UDMA, Dimethacrylate } \\
\text { ULS and BIS-EMA resin. }\end{array}$ & $\begin{array}{l}83 \text { wt } \%, \\
67 \text { vol } \%\end{array}$ & $0.012 \mu \mathrm{m}$ & $\begin{array}{l}\text { Imicryl, } \\
\text { Konya, } \\
\text { Turkey }\end{array}$ & 18331 & $\mathrm{NC}$ \\
\hline SonicFill & $\begin{array}{l}\text { Bulk fill resin } \\
\text { composite }\end{array}$ & $\begin{array}{c}\text { Glass, oxide, chemicals } \\
\text { (10-30\%);3-trimethoxysilylpropyl } \\
\text { methacrylate(10-30\%); silicon dioxide } \\
\text { (5-10\%);ethoxylated bisphenol-A- } \\
\text { dimethacrylate(1-5\%); bisphenol-A-bis- } \\
\text { (2-hydroxy-3-mehacryloxypropyl) ether } \\
\text { (1-5\%);triethylene glycol dimethacrylate } \\
\text { (TEGDMA) (1-5\%). }\end{array}$ & $\begin{array}{c}83.5 \\
\text { wt } \%, 83 \\
\text { vol } \%\end{array}$ & unreported & $\begin{array}{l}\text { Kerr Corp, } \\
\text { Orange, } \\
\text { USA }\end{array}$ & 5450784 & SF \\
\hline Dyract-XP & $\begin{array}{l}\text { Polyacid } \\
\text { Modified Resin } \\
\text { Composite } \\
\text { (Compomer) }\end{array}$ & $\begin{array}{c}\text { UDMA, carboxylic acid modified } \\
\text { dimethacrylate, TEGDMA, } \\
\text { trimethacrylate resin (TMPTMA), } \\
\text { dimethacrylate resins, camphorquinone, } \\
\text { ethyl-4 (dimethylamino) benzoate, } \\
\text { butylated hydroxy toluene (BHT), } \\
\text { strontium-alumino-sodium-fluoro } \\
\text { phosphor-silicate glass, highly } \\
\text { dispersed silicon dioxide, strontium } \\
\text { fluoride, iron oxide pigments and } \\
\text { titanium oxide pigments. }\end{array}$ & $\begin{array}{l}73 \text { wt. } \% \\
47 \text { vol } \%\end{array}$ & $0.8 \mu \mathrm{m}$ & $\begin{array}{l}\text { Dentsply, } \\
\text { DeTrey, } \\
\text { Konstanz, } \\
\text { Germany }\end{array}$ & 1711000413 & DXP \\
\hline
\end{tabular}

Table 2. Chemical compositions of the mouthwashes.

\begin{tabular}{|c|c|c|c|c|}
\hline Mouthwashes & Manufacturer & Chemical composition & $\mathrm{pH}$ & Code \\
\hline Andorex & $\begin{array}{c}\text { Delta Vital, Istanbul, } \\
\text { Turkey }\end{array}$ & $\begin{array}{l}\text { 0.15\% Benzydamine HCL and } 0.12 \% \text { Chlorhexidine } \\
\text { Gluconate, glycerol, ethanol, sorbitol, E102, polysorbate } \\
20 \text {, patent blue V, mint flavor. }\end{array}$ & $5.5-7$ & $A X$ \\
\hline $\begin{array}{l}\text { Listerine Total } \\
\text { Care Zero }\end{array}$ & $\begin{array}{l}\text { Johnson and } \\
\text { Johnson Sanitary } \\
\text { Material Industry } \\
\text { Trade Ltd. Comp. } \\
\quad \text { Turkey }\end{array}$ & $\begin{array}{l}\text { Water, sorbitol, propylene glycol, poloxamer } 407 \text {, } \\
\text { sodium lauryl sulfate, aroma, eucalyptol, zinc chloride, } \\
\text { benzoic acid, sodium benzoate, methyl salicylate, } \\
\text { thymol, sodium saccharin, menthol, sucralose, cl16035, } \\
\text { cl42090, sodium fluoride (220ppm). }\end{array}$ & 3.57 & LT \\
\hline Meridol & $\begin{array}{l}\text { Colgate-Palmolive, } \\
\text { Hamburg, Germany }\end{array}$ & $\begin{array}{l}\text { Aqua, Xylitol, PVP, PEG-4 Hydrogenated Castor Oil, } \\
\text { Olaflur, Aroma, Stannous Fluoride, Sodium Saccharin, } \\
\text { Cl } 42051 .\end{array}$ & 5 & $\mathrm{ML}$ \\
\hline Distilled Water & - & - & 6.7 & DW \\
\hline
\end{tabular}




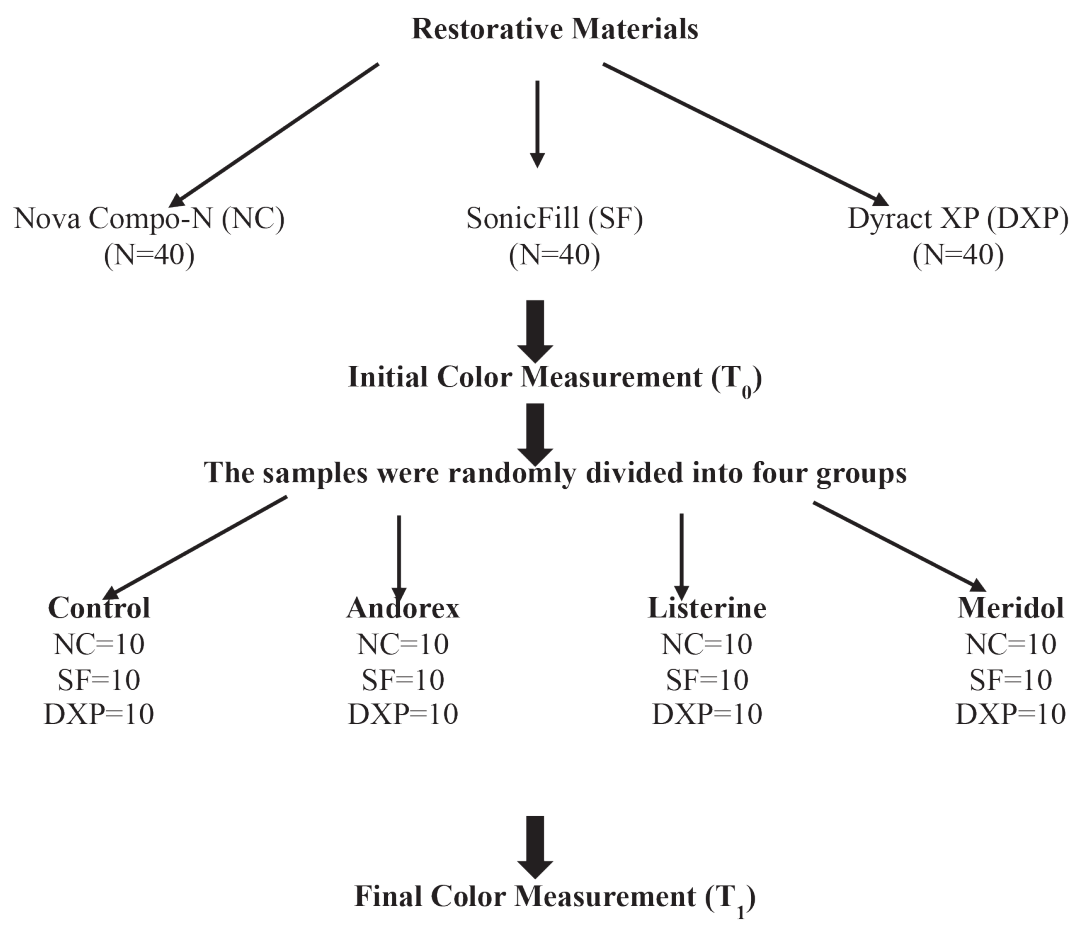

Figure 1. Schematic study design

\section{RESULTS}

The color change values of the materials immersed in different mouthwashes are summarized in Table 3. Our findings revealed a statistically significant difference among the resin-based restorative materials and mouthwashes $(p<0.05)$. The interaction between the type of mouthwash and the type of restorative material was also statistically significant $(p<0.05)$.

The means and standard deviations of the $\Delta E_{00}$ values of the restorative materials after mouthwash immersion are presented in Table 4. All the samples exhibited discoloration after immersion. The highest $\Delta$ Eoo values were observed in the SF group, regardless of mouthwash type, with the difference among the restorative materials being significant $(p<0.05)$. Whereas imperceptible $\Delta E_{00}$ values were found in the NC and DXP groups, perceptible and acceptable $\Delta$ Eoo values were detected in the SF group. The samples immersed in ML exhibited significantly less color change, regardless of restorative material $(p<0.05)$.

The detailed analysis revealed a perceptible color change in all the samples immersed in AX. Perceptible color changes were also observed in the SF-distilled water, SF-ML, and NC-distilled water groups. In contrast to the other groups, the SF-LT samples manifested clinically unacceptable discoloration $\left(\triangle \mathrm{E}_{00}=2.63\right)$. 
Table 3. ANOVA results for color change $\left(\Delta \mathrm{E}_{00}\right)$.

\begin{tabular}{lcccc}
\hline & $\begin{array}{c}\text { Type III Sum of } \\
\text { Squares }\end{array}$ & Mean Square & F-value & p-value \\
\hline Material & 24,260 & 12,130 & 25,259 &, $000^{*}$ \\
Mouthwash & 8,688 & 2,896 & 6,030 &, $001^{*}$ \\
Material *Mouthwash & 13,142 & 2,190 & 4,561 &, $000^{*}$ \\
\hline
\end{tabular}

*Statistically significant, $p<.05$

Table 4. The mean and standard deviations of $\Delta \mathrm{E}_{\mathrm{oo}}$ values.

\begin{tabular}{|c|c|c|c|c|c|}
\hline \multirow[t]{2}{*}{ Materials } & \multicolumn{4}{|c|}{ Mouthwashes } & \multirow[t]{2}{*}{ Total } \\
\hline & DW & $A X$ & ML & LT & \\
\hline NC & $1,59 \pm 0,53^{*}$ & $1,60 \pm 0,26^{*}$ & $0,71 \pm 0,17$ & $1,13 \pm 0,65$ & $1,26 \pm 0,57^{a}$ \\
\hline SF & $2,21 \pm 0,56^{*}$ & $1,59 \pm 0,54$ * & $2,07 \pm 0,67^{\star}$ & $2,63 \pm 0,90^{\star *}$ & $2,12 \pm 0,75^{\star b}$ \\
\hline DXP & $1,16 \pm 0,96$ & $1,77 \pm 1,32^{*}$ & $0,30 \pm 0,25$ & $1,17 \pm 0,63$ & $1,10 \pm 1,00^{a}$ \\
\hline Total & $1,65 \pm 0,81^{\star a}$ & $1,65 \pm 0,81$ *a & $1,03 \pm 0,87 b$ & $1,64 \pm 1,00$ *a & \\
\hline
\end{tabular}

$\Delta$ Eoo values of restorative materials after immersion in mouthwashes at different $\mathrm{pH}$ values.

Capital letters indicate the difference between lines and lower letters indicate the difference between columns $(p<.05)$

${ }^{*}$ perceptibility $>1.30{ }^{* *}$ unacceptability $>2.25$.

\section{DISCUSSION}

This study assessed the effects of three commercially available mouthwashes on the color stability of three resin-based restorative materials. The first null hypothesis tested was rejected in light of the study findings. That is, two of the mouthwashes tested (AX and LT) caused discoloration similar to the control group, whereas the ML caused significantly less discoloration than that induced by the two other varieties. The second null hypothesis was also rejected given the significant difference found among the restorative materials in terms of color stability. The color changes caused by the mouthwashes were acceptable, except for those in the SF-LT group.

In restorative materials, color changes stemming from intrinsic and extrinsic factors can be evaluated visually and with the use of instrumental techniques (spectrophotometry and colorimetry) (18). Visual color assessment is unreliable because of interobserver inconsistencies in color perception. Instrumental measurements are therefore widely used to measure color changes in dental materials as these approaches eliminate subjective interpretation $(7,19)$. Brewer et al. (20) showed that spectrophotometers are more accurate than colorimeters in determining color variations.

Many color specification systems have been proposed to improve the identification of the correlation between color measurement and visual perception in the spectrophotometer One such system is the CIE L*a*k* (CIELAB) system, which was developed in 1978 by the Commission Internationale de l'Eclairage (CIE). In this system, $L^{*}$ represents lightness, $a^{*}$ denotes the green-red axis $(-a=g r e e n ;+a=r e d)$, and $b^{*}$ indicates the blue-yellow axis (-b=blue; $+b=y e l l o w) ~(21)$. In 2001, the CIE developed CIEDE2000 to overcome the deficiencies in the CIE $L^{*} a^{*} b^{*}$ formula (14). 
Despite the superiority of the new formula, however, it is also more complex to use $(22,23)$. As explained by Gomez et al. (23), the CIEDE2000 formula could be better adapted to calculations of color differences and provide an enhanced indication of perceptibility and acceptability. In the present study, the CIEDE2000 system was used for color measurements intended to detect color changes caused by the immersion of resin-based restorative materials in mouthwashes.

Visual perceptibility and acceptability thresholds are important concepts of color changes in dentistry (24). When the color difference is visible to $50 \%$ of observers, this phenomenon is known as the perceptibility threshold. When the color difference is considered acceptable by $50 \%$ of observers, this occurrence is defined as the acceptability threshold (25). Ghinea et al. (17) calculated perceptibility and acceptability thresholds using the CIEDE2000 formula and derived values of $<1.30$ and $<2.25$, respectively. The same figures were used as threshold values in the current research.

Time of exposure to external factors that affect color stability in esthetic restorations is an essential determinant of the degree of color change. The 12-hour immersion time used in in-vitro studies is considered equivalent to the use of mouthwashes for two minutes a day for a year (26). The samples in the present study were immersed in three types of mouthwash and distilled water (control group) at $37^{\circ} \mathrm{C}$ for $24 \mathrm{~h}$ (13)-a period equivalent to 2-minute daily mouth rinsing for two years. However, mouthwashes are used in daily life for 1 minute twice a day. During the rest of the day, teeth and restorations are in contact with saliva. Saliva has a cleaning feature in terms of its content. It reduces coloration that may occur on teeth or restorations. In our study, it is thought that 24 hours of continuous contact with mouthwashes and the lack of cleaning effect of saliva may cause coloration to be seen more than usual.
Given the increasing consequence of esthetic appearance in dentistry, resin-containing materials have recently been employed progressively in both primary and permanent dentitions (11). Compomers that exert anti-caries effects due to fluoride release are generally preferred in pediatric and restorative dentistry (27), but composite resins are the most commonly used restorative materials (3). This preference is driven by the esthetic properties, high adhesion strength to dental tissues and minimally invasive cavity preparation enabled by composite resins (28). Contrastingly, the application of traditional composites requires the use of an incremental restorative technique owing to their limited depth cure; traditional composite techniques are therefore time-consuming (29). This disadvantage can be eliminated using bulk-fill resin composites, which have more sensitive photo-initiators that allow a polymerization depth of 4 to $6 \mathrm{~mm}$ (3). Given that no layering technique is required in these formulations, they shorten the period taken to complete restorative procedures and reduce chair time (30). Despite these merits, all resin-based restorative materials are expected to provide long-term survival in the mouth. However, these restorations need to be renewed within approximately four years because of discoloration $(31,32)$. An important requirement, therefore, is to understand the discoloration potential of restorative materials and decide on options on the basis of daily diet, drug use, and mouthwash use. The present study assessed color stability of the nanohybrid composites, bulk-fill resin composites, and compomers, which are all widely used and commercially available restorative materials.

Some properties of resin-based restorative materials may result in a greater incidence of external discoloration. Intrinsic factors that affect discoloration include matrix composition, the size/volume of fillers, and photo-initiators (4). Susceptibility to staining can also be caused by the type of resin matrix used (33). Resin matrices composed of urethane dimethacrylate (UDMA), for example, are more 
durable than those containing bisphenol A-glycidyl methacrylate (Bis-GMA) because they have lower water absorption and solubility properties. The high viscosity of a Bis-GMA matrix is diluted by the addition of triethylene glycol dimethacrylate (TEGDMA). TEGDMA has a high affinity to water molecules, thereby enriching the hydrophilic properties of resin composites (34). Hydrophilic materials exhibit a relatively higher degree of absorption and discoloration from dye-containing solutions than do hydrophobic materials (35). The materials used in the current research were NC with Bis-GMA and dimethacrylate, SF with Bis-GMA and TEGDMA, and DXP with UDMA and TEGDMA. The greater color change in the SF samples may be associated with the monomer component (TEGDMA) incorporated into them. Consistent with the results of our research, a previous study reported that SonicFill exhibits more discoloration than do nanohybrid composites (9). The low discoloration rate in the DXP samples in our work is also attributed to the UDMA monomer concentration in the matrix.

Mouthwash, which is one of the extrinsic factors that may cause discoloration in teeth, restorations, and even oral mucosa, has been studied by researchers $(11,12,26,27)$. The color change is one of the well-known side-effects of chlorhexidine mouthwashes (4). Fluoride is added to mouthwashes for its remineralization effect, but it contributes to a certain extent to color change in resin composite materials (9). Zinc is also added to some mouthwashes for plaque control, malodor reduction, and anti-tartar effects. This element maintains its presence in plaque and saliva for extended periods, thus causing perceptible discoloration in resin composites (Table 2) (9). Interestingly, water content also affects discoloration, and the same effects as those exhibited by mouthwashes can also arise from the use of distilled water (36). Consistent with these reports, the $A X$ and distilled water groups in the present study generated clinically detectable color changes in all the samples, but no statistically significant difference was observed among them ( $p>0.05)$. Ulusoy et al. (11) examined the effects of four mouthwashes and distilled water on discoloration in composite resins, compomers, giomers, and resin-modified glass ionomers. As with the current research, discoloration was observed in all materials immersed in distilled water, but no statistically significant difference was found among them. This finding also agrees with those derived by Eslami et al. (37) and Çelik et al. (38). Although the staining effect of distilled water was expected to be the lowest among the groups, it is thought that the result obtained vice versa may be caused by the distillation method and the device used.

Öztürk-Bozkurt et al. (9) evaluated the effects of four mouth rinses [Oral-B Pro-Expert Clinic Line Alcohol free (with sodium fluoride content), Listerine Tooth Defense, Pharmol Zn (containing zinc chloride), and Nilera (containing Zinc sulfate)] on the color stability of two resin composites [SonicFill (Kerr) and Filtek Z550 (3M ESPE)]. The authors reported that SonicFill shows significantly high discoloration when exposed to Oral-B Pro Expert Clinic Line Alcohol-Free Mouthwash, Listerine Tooth Defense Rinse, and Pharmol Zn Mouth Rinse. They also found no statistically significant color differences in the materials immersed in distilled water and Nilera Mouth Rinse. In the present study, while ML (with stannous fluoride content) caused perceptible discoloration only in the SF group, but the color changes in the other resin-based composite groups were imperceptible. Listerine $₫$ (containing zinc chloride and sodium fluoride) produced unacceptable discoloration in the SF group but imperceptible discoloration in the NC and DXP groups. The considerable color change in SF may be due to the TEGDMA monomer. Furthermore, the $\mathrm{pH}$ of the tested mouthwashes provides another possible predisposing factor for the composite matrix degradation. The low $\mathrm{pH}$ of active ingredients of mouthwashes may influence color, surface hardness, and wear. Compared to distilled water 
$(\mathrm{pH}=6.7)$ the higher acidity (Listerine-pH:3,57) may have changed the polymeric matrixes of the resin composite by catalysis of ester groups from dimethacrylate monomers (Bis-GMA, Bis-EMA, UDMA or TEGDMA) (Table 2). The hydrolysis of these ester groups may have created alcohol and carboxylic acid molecules, which accelerate the degradation of the resin composites, due to the decrease of pH inside the resin matrix (39).

Successful restoration depends on the selection of an appropriate material for each oral environment. The storage medium used in our study could not completely simulate oral medium because it did not contain oral microflora, saliva, or nutrients that may also influence color changes in restorations. This is the principal limitation of our research. The second limitation is the immersion of the samples continuously in the mouthwashes. Although this period is equivalent to the two-year total use of mouthwash, it cannot accurately reflect the effects of intermittent use of mouthwashes. Therefore, further clinical studies should be designed to determine the discoloration degree of mouthwashes in the mouth environment.

\section{CONCLUSION}

Considering that it will contribute to the practice of clinicians, the staining effects of the updated content of frequently prescribed mouthwashes on the long-term aesthetic properties of new resin-based materials were evaluated. Within the limitations of an in vitro investigation, nonetheless, we can conclude that the effects of the mouth rinses on the color change of the materials were not different from that of control solution except Meridol@. Resin-based materials exposed to Meridol ${ }^{\circledR}$ are significantly less vulnerable to color change. In terms of color stability, among the restorative materials, SonicFill is more susceptible to discoloration than are the other composite resin materials. However, the current results obtained should be supported by further in vitro studies using different immersion times. Clinicians should be aware of the potential of mouthwash prescribed for daily use to cause staining on restorative materials.

\section{REFERENCES}

1. Francisconi-dos-Rios L.F., Tavares J.A.O., Oliveira L., Moreira J.C., Nahsan F.P.S. Functional and aesthetic rehabilitation in posterior tooth with bulk-fill resin composite and occlusal matrix. Restor Dent Endod 2019; 45 (1): 1-7.

2. Blumer S., Peretz B., Ratson T. The Use of Restorative Materials in Primary Molars among Pediatric Dentists in Israel. J Clin Pediatr Dent 2017; 41 (3): 199-203.

3. Van Ende A., De Munck J., Lise D.P., Van Meerbeek B., Ermis B. Bulk-fill composites: a review of the current literature. J Adhes Dent 2017; 19 (2): 95-109.

4. Menon A., Ganapathy D.M., Mallikarjuna A.V. Factors that influence the colour stability of composite resins. Drug Invent Today 2019; 11 (3): 744-749.

5. Barutcigil Ç., Yıldız M. Intrinsic and extrinsic discoloration of dimethacrylate and silorane based composites. J Dent 2012; 40: 57-63.

6. Tekçe N., Tuncer S., Demirci M., Serim M.E., Baydemir C. The effect of different drinks on the color stability of different restorative materials after one month. Restor Dent Endod 2015; 40 (4): 255-261.

7. Guler A.U., Yilmaz F., Kulunk T., Guler E., Kurt S. Effects of different drinks on stainability of resin composite provisional restorative materials. J Prosthet Dent 2005; 94 (2): 118-124.

8. Soygun K., Varol O., Ozer A., Bolayir G. Investigations on the effects of mouthrinses 
on the colour stability and surface roughness of different dental bioceramics. J Adv Prosthodont 2017; 9 (3): 200-207.

9. Bozkurt F.Ö., Akalın T.T., Genç G., Ceyhan Y.K. The effect of mouthrinses on color stability of sonicfill and a nanohybrid composite. J Istand Univ Fac Dent 2016; 50 (2):17-23.

10. Müller H.D., Eick S., Moritz A., Lussi A., Gruber R. Cytotoxicity and antimicrobial activity of oral rinses in vitro. BioMed Res Int 2017; 1:1-9.

11. Ulusoy N., Arikan V., Oba A.A. Effect of mouthwashes on the discolouration of restorative materials commonly used in paediatric dentistry. Eur Arch Paediatr Dent 2018; 19 (3): 147-153.

12. ElEmbaby A.E.S. The Effects of Mouth Rinses on the Color Stability of Resin-Based Restorative Materials. J Esthet Restor Dent 2014 ; 26 (4): 264-271.

13. Baig A.R., Shori D.D., Shenoi P.R., Ali S.N., Shetti S., Godhane A. Mouthrinses affect color stability of composite. J Conserv Dent 2016; 19 (4): 355.

14. Luo M.R., Cui G., Rigg B. The development of the CIE 2000 colour-difference formula: CIEDE2000. Color Research \& Application: Endorsed by Inter-Society Color Council, The Colour Group (Great Britain), Canadian Society for Color, Color Science Association of Japan, Dutch Society for the Study of Color, The Swedish Colour Centre Foundation, Colour Society of Australia, Centre Français de la Couleur 2001; 26 (5): 340-350.

15. De Oliveira D.C.R.S., Ayres A.P.A., Rocha M.G., Giannini M., Puppin Rontani R.M., Ferracane J.L., et al. Effect of Different In Vitro Aging Methods on Color Stability of a Dental Resin-Based Composite Using CIELAB and CIEDE 2000 Color-Difference Formulas. J Esthet Restor Dent 2015; 27 (5): 322-330.
16. Pecho O.E., Ghinea R., Alessandretti R., Pérez M.M., Della Bona A. Visual and instrumental shade matching using CIELAB and CIEDE2000 color difference formulas. Dent Mater 2016; 32 (1): 82-92.

17. Ghinea R., Pérez M.M., Herrera L.J., Rivas M.J., Yebra A., Paravina R.D. Color difference thresholds in dental ceramics. J Dent 2010; 38:57-64.

18. Okubo S.R., Kanawati A., Richards M.W., Childressd S. Evaluation of visual and instrument shade matching. J Prosthet Dent 1998; 80 (6): 642-648.

19. Maitin S.N., Maitin N., Priyank H., Raj S. Evaluation of spectrophotometer analysis of bulk-fill composites in various daily used beverages. Int J Med Biomed Stud 2019; 3 (10): 334-341.

20. Brewer J.D., Wee A., Seghi R. Advances in color matching. Dent Clin North Am 2004; 48 (2): 341-358.

21. Rosenstiel S.F., Johnston W.M. The effects of manipulative variables on the color of ceramic metal restorations. J Prosthet Dent 1988; 60 (3): 297-303.

22. Sharma G., Wu W., Dalal E.N. The CIEDE2000 color-difference formula: Implementation notes, supplementary test data, and mathematical observations. Color Research \& Application: Endorsed by Inter-Society Color Council, The Colour Group (Great Britain), Canadian Society for Color, Color Science Association of Japan, Dutch Society for the Study of Color, The Swedish Colour Centre Foundation, Colour Society of Australia, Centre Français de la Couleur 2005; 30 (1): 21-30.

23. Gómez-Polo C., Muñoz M.P., Luengo M.C.L., Vicente P., Galindo P., Casado A.M.M. Comparison of the CIELab and CIEDE2000 color difference formulas. J Prosthet Dent 2016; 115 (1): 65-70.

24. Chu S.J., Trushkowsky R.D., Paravina R.D. Dental color matching instruments and 
systems. Review of clinical and research aspects. J Dent 2010; 38:2-16.

25. Paravina R.D., Swift Jr E.J. Color in dentistry: match me, match me not. J Esthet Restor Dent 2009; 21 (2): 133-139.

26. Gürgan S., Önen A., Köprülü H. In vitro effects of alcohol-containing and alcoholfree mouthrinses on microhardness of some restorative materials. J Oral Rehabil 1997; 24 (3): 244-246.

27. Gürdal P., Akdeniz B.G., Hakan Sen B. The effects of mouthrinses on microhardness and colour stability of aesthetic restorative materials. J Oral Rehabil 2002; 29 (9): 895-901.

28. Demarco F.F., Corrêa M.B., Cenci M.S., Moraes R.R., Opdam N.J. Longevity of posterior composite restorations: not only a matter of materials. Dent Mater 2012; 28 (1): 87-101.

29. Rees J., Jagger D., Williams D., Brown G., Duguid W. A reappraisal of the incremental packing technique for light cured composite resins. J Oral Rehabil 2004; 31 (1): 81-84.

30. Kim E.H., Jung K.H., Son S., Hur B., Kwon Y.H., Park J.K. Effect of resin thickness on the microhardness and optical properties of bulk-fill resin composites. Restor Dent Endod 2015; 40 (2): 128-135.

31. Barnes D., Blank L., Thompson V., Holston A., Gingell J. A 5-and 8-year clinical evaluation of a posterior composite resin. Quintessence Int 1991; 22 (2):143-151.

32. Chrysanthakopoulos N.A. Placement, replacement and longevity of composite resin-based restorations in permanent teeth in Greece. Int Dent J 2012; 62 (3):161-166.

33. Villalta P., Lu H., Okte Z., Garcia-Godoy F., Powers J.M. Effects of staining and bleaching on color change of dental composite resins. J Prosthet Dent 2006; 95 (2):137-142.

34. Ren Y.F., Feng L., Serban D., Malmstrom H.S. Effects of common beverage colorants on color stability of dental composite resins: the utility of a thermocycling stain challenge model in vitro. J Dent 2012; 40:48-56.

35. Bagheri R., Burrow M., Tyas M. Influence of food-simulating solutions and surface finish on susceptibility to staining of aesthetic restorative materials. J Dent 2005; 33 (5): 389-398.

36. Geurtsen W., Leyhausen G., Garcia-Godoy F. Effect of storage media on the fluoride release and surface microhardness of four polyacidmodified composite resins ("compomers"). Dent Mater 1999; 15 (3):196-201.

37. Eslami N., Ahrari F., Rajabi O., Zamani R. The staining effect of different mouthwashes containing nanoparticles on dental enamel. J Clin Exp Dent 2015; 7 (4): 457.

38. Celik C., Yuzugullu B., Erkut S., Yamanel K. Effects of mouth rinses on color stability of resin composites. Eur J Dent 2008; 2 (04): 247-253.

39. Almeida G.S., Poskus L.T., Guimarães J.G., da Silva EM. The effect of mouthrinses on salivary sorption, solubility and surface degradation of a nanofilled and a hybrid resin composite. Oper Dent. 2010 Jan-Feb; 35 (1): 105-111. 